\title{
Yalanın Uygunluğu Ölçeğinin Geliştirilmesi: Geçerlik ve Güvenirlik Çalışması
}

\author{
Sercan BALIM ${ }^{1}$, Muhammed Şükrü AYDIN ${ }^{2}$
}

\section{ÖZET}

$\mathrm{Bu}$ çalışmada, Türkiye'deki üniversite öğrencileri ve yetişkinlerin hangi tür yalanları uygun bulduklarının incelenmesi amacıyla geliştirilen "Yalanın Uygunluğu Ölçeğinin" geçerlik ve güvenirlik analizlerinin yapılması hedeflenmiştir. Çalışmaya, yaşları 18 ile 66 arasındaki (Ortyaş= 27.55) 615 kişi katılmıştır. Katılımcılara, araştırmacılar tarafından geliştirilen Yalanın Uygunluğu Ölçeğinin yanı sıra Dürüstlük Ölçeği uygulanmıştır. Geçerlik çalışmaları kapsamında, açımlayıcı faktör analizi gerçekleştirilmiş ve ölçeğin son halinin 9 maddeli "kendini koruma yalanları", 6 maddeli "imaj yönetimi yalanları", 7 maddeli "prososyal yalanlar", 5 maddeli "geçiştirme yalanları", 4 maddeli "zorunlu yalanlar" ve 4 maddeli "araçsal yalanlar" olmak üzere toplamda 35 maddeden oluşan altı faktörlü bir yapıya sahip olduğu bulunmuştur. Ayrıca, testin iç-tutarlılık katsayıları ve üç hafta ara ile yapılan uygulamalar sonucunda hesaplanan test-tekrar test güvenirlik katsayıları testin oldukça güvenilir olduğunu göstermiştir. Bulgular, "Yalanın Uygunluğu Ölçeğinin" ilgili örneklemde kullanılabilecek geçerli ve güvenilir bir ölçme aracı olduğunu ortaya koymuştur.

Anahtar Kelimeler: Yalan, kandırma, yalanın uygunluğu, yalan söyleme nedenleri.

\section{The Development of Reasonability of Lying Scale: The Validity and Reliability Study}

\begin{abstract}
The aim of this study is to examine which types of lies are more reasonable for university students and adults in Turkey, and to conduct the validity and reliability analysis of the "Reasonability of Lying Scale". Six hundred and fifteen people aged between 18 and $66(\mathrm{M}=27.55)$ participated in the study. Participants were given Integrity Scale in addition to Reasonability of Lying Scale developed by the researchers. Within the scope of validity studies, an exploratory factor analysis was performed and the final version of the scale had a total of 35 items and six factors including 9-item named "self-protection lies", 6-item named "face management lies", 7-item named "prosocial lies", 5-item named "evading lies", 4-item named "necessity lies" and 4-item named "instrumental lies". Moreover, the internal consistency coefficients and the test-retest reliability coefficients calculated as a result of the applications made in three-week interval showed that the test was quite reliable. Results revealed that "Reasonability of Lying Scale" is a valid and reliable tool that can be used in the relevant sample.
\end{abstract}

Keywords: Lying, deception, reasonability of lying, motivations of lying.

\footnotetext{
${ }^{1}$ Doktora Öğrencisi, İstanbul Üniversitesi, Psikoloji Doktora Programı, balimsercan@gmail.com

${ }^{2}$ Gelişim Psikoloğu, Doktor, msukruaydin@hotmail.com
} 


\section{GíRIŞ}

Yalan söyleme ve kandırma, insanlar arasında çok yaygın görülen sosyal bir davranıştır. Günlük hayatta yalanla ilişkili birçok kavram olması çok farklı tanımların yapılmasına neden olmuştur. Ancak genel olarak "kandırmayı" niyetli ve amaçlı bir şekilde başkalarına aldatıcı davranışlarda bulunma olarak tanımlayan Levine (2014), yalan söyleme davranışını ise kandırmanın bir türü olarak değerlendirmektedir. Levine'e göre yalan, söyleyen kişi tarafindan doğru olmadığı bilinen ve aynı zamanda dinleyiciye ilettiği mesajın doğru olduğuna inandırma niyeti taşıyan gerçek dışı ifadelerdir.

Her ne kadar bütün toplumlarda dürüstlük değerine önem veriliyor, aldatıcı davranışlar hoş karşılanmıyor olsa da, bu tür davranışların insanlar arasındaki etkileşimlerde neredeyse her gün ortaya çıktığı söylenebilir (Serota, Levine ve Boster, 2010). Bu sebeple, insanların ne zaman ve neden yalan söyledikleri, neleri yalan olarak algıladıkları, yalan söylediklerinde bunu nasıl meşrulaştırdıklarını anlamak için yalanın ortaya çıkışını tetikleyen durumların saptanması da önem kazanmıştır (McCornack, Morrison, Paik, Wisner ve Zhu, 2014). Bunun yanı sıra, sosyal bir davranış olması nedeniyle toplumsal etkilerin yalan söyleme davranışlarının önemli bir yordayıcısı olduğu da yeterince açıktır (bkz. Fu, Evans, Wang ve Lee, 2008). Bu nedenle, yalan konusunu kültürler özelinde ele almak farklı bakış açılarının görülmesine yardımcı olabilir.

Kültür, gelişimin erken dönemlerinden itibaren insanların deneyimlerini ve bu deneyimlere atfetmiş olduğu anlamları belirleyen değer, tutum ve inançlarını kapsayan bir sistemdir. Dolayısıyla, farklı kültürlerde yetişen insanların yalan söyleme davranışlarına ilişkin algı ve yorumları da doğal olarak farklılaşmaktadır (Lee, Cameron, Xu, Fu ve Board, 1997). Aslında yalana ilişkin ahlaki yargılarımızın kültürden etkilenip etkilenmediği üzerine yapılan felsefi tartışmalara yüzyıllar öncesinde rastlanmaktadır. Mutlakçı görüş, yalan söylemenin kültürel etmenler ve bağlamdan bağımsız olarak uygun bir davranış olmadığını savunsa da; sosyal-geleneksel yapıların önemini vurgulayan faydacı görüş, bir yalanın doğru ya da yanlış olup olmadığının niyetin yanı sıra sosyokültürel etmenler tarafından da belirlendiğini savunmaktadır (Tartışma için bkz. Bok, 1978). Buna göre, kültürün, yalan söyleme nedenleri ve yalana ilişkin değerlendirmeleri etkilediği ve yalan söylemenin bütün toplumlarda evrensel olarak yanlış bir davranış şeklinde değerlendirilmesinin uygun olmadığı söylenebilir.

Evans ve Lee (2013), konuşma-eylem yaklaşımından faydalanarak insanların yalan söyleme davranışlarında iki önemli bileşenden söz etmektedir: "niyetlilik" ve "gelenekçilik". Bu yaklaşım, iki bileşenin aslında yalan söyleme davranışlarını ve bunlar hakkındaki yargılarımızı etkileyen bilişsel ve kültürel etmenlerle bağlantılı olduğunu savunmaktadır. Niyetliliğin bilişsel süreçlerle, gelenekçiliğin ise kültürel etmenlerle ilişkili olduğu düşünülmektedir. Buna göre ilk olarak, konuşan kişinin amacının ne olduğu önemlidir. Bir diğer ifadeyle, konuşan kişinin iletişime yardımcı mı olduğu yoksa zarar mı verdiği meselesi birincil odak noktasıdır. Ardından belirli bir bağlam özelinde sosyal ve kültürel faktörlerin iletişime nasıl aracılık ettiği meselesi devreye girmektedir. "Gerçek olmayan ifade insanların içinde bulunduğu ortam için gerekli mi?", "bir ortamda naziklik mi yoksa bilginin doğruluğu mu ön planda tutulmalı?" gibi sorular önem kazanmaktadır. Özetle, hem yalan söyleyen kişinin hangi niyeti taşıdığı, hem de bir bağlam içerisinde sosyal ve kültürel etmenlere göre yalanın nasıl değerlendirildiği konusu önem arz etmektedir (Evans ve Lee, 2013).

Yalan söyleme nedenleri, yalanın kabul edilebilirliği ve yalanın algılanma biçimleri gibi konularda kültürler arası farklılık ve benzerliklerin ele alındığı çalışmalar mevcuttur. Bu çalışmaların bir kısmı bireyci ve toplulukçu kültür karşılaştırmalarına dayanmaktadır (bkz. Triandis ve ark., 2001). Buna göre, toplulukçu kültürlerde yetişenlerin sosyal ilişkilere ve grubun bütünlügüne önem vermesi nedeniyle başkası yararına söylenen yalanların bu toplumlarda daha yüksek olması beklenebilir. Alan yazın incelendiğinde, bu açıklamalara paralel ampirik çalışmaların yer aldığı görülmektedir. Örneğin, Kanadalıların yalanlar başkası yararına olsa dahi o yalanları Çinlilere göre daha olumsuz değerlendirdikleri ( $\mathrm{Fu}$, Lee, Cameron ve $\mathrm{Xu}, 2001)$, Amerikalıların daha net ve anlaşılır mesajları tercih etmelerinden dolayı Korelilere kıyasla muğlaklık içeren ifadeleri yalana daha yakın gördükleri (Park ve Ahn, 2007) gibi bulgulara rastlanmaktadır. Buna benzer açıklamalar, yalanın kabul edilebilirliğinin kültürlere göre farklılaştığı konusunda da yapılmaktadır. Örneğin, $\mathrm{Fu}, \mathrm{Xu}$, Cameron, Heyman ve Lee (2007), 12 yaşından küçük Çinli çocukların Kanadalı çocuklara kıyasla grup yararı için 
söylenen yalanları daha olumlu değerlendirdiklerini bulmuşlardır. Ayrıca, yalanlar bir başkasının yararına yapılacak bir eylem nedeniyle söylendiğinde, Çinli çocukların Kanadalı akranlarıyla karşılaştırıldıklarında bu tür yalanları da daha olumlu gördükleri bulunmuş ve sonuçlar araştırmacılar tarafından Çin kültüründe hâkim olan alçak gönüllülük etkisiyle açıklanmıştır (Lee ve ark., 1997; Lee, $\mathrm{Xu}, \mathrm{Fu}$ ve Chen, 2001).

Görüldüğg̈ üzere alan yazında kültüre göre yalanın nasıl değerlendirildiği, hangi durumlarda makul karşılandığı gibi konularda çalışmalar yürütülmüştür. Kavramsal olarak bakıldığında, yalanın kabul edilebilirliği yahut uygunluğu, bir kişinin yalan ve kandırma davranışlarını genel olarak değerlendirmesi şeklinde ifade edilebilir (Oliveira ve Levine, 2008). İnsanlar bu değerlendirmeyi yaparken, iyi-kötü, olumlu-olumsuz, uygun-uygun değil ya da kabul edilebilir-kabul edilemez gibi yargılara dayanmaktadır. Bir diğer ifadeyle, yalanın uygunluğu ya da kabul edilebilirliği yalana ilişkin genel bir değerlendirme veya tutumu yansıtmaktadır.

Yalanın uygunluğu araştırmalarda farklı ölçme yöntemlerinin kullanıldığı görülmektedir (Örn., Cantarero, Szarota, Stamkou, Navas ve Dominguez Espinosa, 2018; Oliveira ve Levine, 2008). Örneğin Oliviera ve Levine'nin (2008) çalışmasında, yalana ilişkin genel ifadelerle (örn., “yalan söylemek kötüdür"; "birini incitmektense yalan söylemek daha iyidir" gibi) bireysel tutumların incelendiği görülmektedir. Bazı çalışmalarda ise yalan ve doğru söylemeyle ilgili hikayeler kullanılarak bireylerin bu senaryolara ilişkin düşünceleri sorulmaktadır (Bkz. Choi, Park ve Oh, 2011; Fu ve ark., 2001). Bu tip çalışmalarda prososyal ve antisosyal şeklinde genel yalan kategorileri kullanılmakta ancak her bir kategoride ayrı ayrı hangi motivasyonlarla yalan söylendiği meselesi detaylı olarak ele alınmamaktadır. Yalan söyleme motivasyonlarından bağımsız bir şekilde yalan söylenerek sonlandırılan bu hikâyelerde katılımcılara yalan söyleme durumuna ilişkin yargılarının neler olduğu sorulmaktadır. Ancak yalanların farklı motivasyonlarla söylenmesi insanların yalanı değerlendirirken göz önünde bulundurdukları bir yön olduğundan bu konu, yalanın uygunluğu çalışmalarında kullanılan ölçüm araçlarında dikkat edilmesi gereken noktalardan biridir. Bu nedenle yalanın uygunluğu konusunda hem farklı yalan söyleme nedenlerini hem de yalandan fayda sağlayan kişi (kendi vs. başkası) üzerinden tasarlanan bir ölçme aracı alan yazında görülen eksikliklerden biri olarak göze çarpmaktadır. Aslında Evans ve Lee'nin (2013) açıklamaları hem yalan söyleme nedeni hem de kültüre özgü etmenlerin yalanın değerlendirilmesinde önemli olduğuna işaret etmektedir. Bu nedenle kültürel etmenlerin çok farklı boyutları olduğu bir ülkede geliştirilen bir ölçme aracının hem ülkenin yapısına uygunluğu, hem de benzer toplumsal özelliklere sahip ülkeler tarafından kullanılabilecek olması nedeniyle yararı olabilir.

Bu noktadan hareketle, Türkiye gibi bireyci ve toplulukçu kültür özelliklerinin bir arada bulunduğu bir ülkeden (Kağıtçıbaşı, 2005) elde edilen verilerle yalanın uygunluğuna ilişkin bir ölçüm aracı geliştirmek, yalanın uygunluğunu değerlendirme konusunda mevcut ölçüm araçlarının sözü edilen eksiklerini gidermeye yönelik alan yazına katkı sağlayabilir. Bunun yanı sıra, bu çalışmada geliştirilmesi planlanan ölçme arac1 ile üniversite öğrencileri ve yetişkinlerin hangi nedenlerle yalan söylediklerini değerlendirmek de mümkün olacaktır. Böylece ileride yalanın uygunluğuna dair çalışmalar yürütecek araştırmacılar, araştırma yapmayı planladıkları farklı katılımcı grupları genel düzeydeki yalanı uygun bulma derecelerinin yanı sıra farklı alt boyutlardaki yalanı uygun bulma derecelerine de bu ölçüm aracını kullanarak ulaşabileceklerdir. Dolayısıyla şimdiki çalışmada öncelikle Türkiye'de kullanılabilecek, yalanın hangi durumlarda ve nedenlerle uygun bulunduğuna yönelik bir ölçme aracını alan yazına kazandırmak amacıyla "Yalanın Uygunluğu Ölçeğinin" geçerlik ve güvenirlik analizleri yapılacaktır.

\section{YÖNTEM}

\section{Katılımcilar}

Çalışmaya Türkiye'nin farklı şehir ve bölgelerinde yaşayan, yaşları 18 ile $66\left(\right.$ Ort $_{\text {yaş }}=27.55$; SS $_{\text {yaş }}=$ 9.19) arasında değişen 404 kadın, 206 erkek ve cinsiyet belirtmeyen 5 kişi olmak üzere toplam 615 kişi katılmıştır. Katılımcılara ulaşmada kartopu örnekleme yöntemi tercih edilmiştir. Katılımcılara ilişkin demografik bilgiler Tablo 1'de gösterilmişstir. 
Tablo 1. Katılımcıların Demografik Bilgileri

\begin{tabular}{|c|c|c|}
\hline Cinsiyet & $\mathbf{N}$ & $\%$ \\
\hline Kadın & $404\left(\mathrm{Ort}_{\mathrm{yass}}=26.39 ; \mathrm{Ss}_{\mathrm{yass}}=9.22\right)$ & 65.7 \\
\hline Erkek & $206\left(\right.$ Ort $\left._{\mathrm{yas}}=29.90 ; \mathrm{Ss}_{\mathrm{yas}}=8.73\right)$ & 33.5 \\
\hline Belirtmek İstemiyorum & $5\left(\right.$ Ort $\left._{\text {yas }}=24.6 ; \mathrm{SS}_{\mathrm{yas}}=8.82\right)$ & 0.8 \\
\hline Eğitim Durumu & $\mathbf{N}$ & $\%$ \\
\hline İlkokul Mezunu & 7 & 1.1 \\
\hline Ortaokul Mezunu & 3 & 0.5 \\
\hline Lise Mezunu & 42 & 6.8 \\
\hline Üniversite Öğrencisi & 298 & 48.5 \\
\hline Üniversite Mezunu & 167 & 27.2 \\
\hline Lisansüstü Öğrencisi & 37 & 6 \\
\hline Lisansüstü Mezunu & 61 & 9.9 \\
\hline Gelir Düzeyi & $\mathbf{N}$ & $\%$ \\
\hline Düşük & 90 & 14.6 \\
\hline Orta & 474 & 77.1 \\
\hline Yüksek & 51 & 8.3 \\
\hline Medeni Durum & $\mathbf{N}$ & $\%$ \\
\hline Evli & 197 & 32 \\
\hline Bekâr & 403 & 65.5 \\
\hline Eş vefatı & 3 & 0.5 \\
\hline Boşanmıș & 12 & 2 \\
\hline Toplam & 615 & 100 \\
\hline
\end{tabular}

Test-tekrar test (üç hafta arayla) güvenirlik katsayısı hesaplaması için ise 19 ile 60 yaşları arasındaki $\left(\right.$ Ort $\left._{\text {yaș }}=30.31 ; \mathrm{SS}_{\text {yaș }}=7.22\right) 36$ erkek, 22 kadına, toplamda ise 58 katılımcıya aynı formlar tekrar uygulanmıştır. Bu katılımcıların \%43.1'i bekâr, \%72.4'ü orta gelir düzeyinde ve \%46.6'sı üniversite mezunudur.

\section{Veri Toplama Araçları}

Demografik Bilgi Formu: Katılımcıların cinsiyet, yaş, eğitim durumu, medeni durum, gelir düzeyi gibi çeşitli demografik özelliklerini belirlemek adına kullanılmış formdur.

Yalanın Uygunluğu Ölçeği: İnsanların, yalan söyleme davranışlarını hangi durumlarda ve ne derece uygun bulduklarını değerlendirmek amacıyla, bu çalışma kapsamında geliştirilen "Yalanın Uygunluğu Ölçeği” kullanılmıştır. 59 maddeden oluşan bu ölçek, farklı yalan söyleme nedenlerindeki örnek durumları içermekte olup 5'li likert tipinde hazırlanmıştır ( $1=$ Hiç uygun değil; $2=$ Uygun değil; $3=$ Kararsızım; 4= Uygun; 5= Tamamen uygun). Ölçeğin tüm maddeleri, çalışmanın sonundaki Ek-1'de sunulmuştur.

Dürüstlük Ölçeği: Bilgiç, Bıkmaz, Esgin ve Şahin'in (2011) geliştirdiği bu ölçek insanların dürüstlük düzeyini ölçmektedir. Beşli likert tipindeki ölçek toplam 20 maddeden oluşmaktadır. Mevcut çalışma kapsamında Yalanın Uygunluğu Ölçeği'nin geçerlik analizlerinde kullanılmak üzere yalan söyleme boyutundaki 8 madde alınmıştır. Üç faktörden (yalan söyleme, hileli davranma, samimiyetsizlik) oluşan ölçeğin güvenirlik katsayılarının sırasıyla $.80, .67, .68$; ölçeğin iç tutarlılık katsayısının ise .78 olarak bulunduğu belirtilmiştir. $\mathrm{Bu}$ çalışmada ise yalan söyleme boyutunun iç tutarlılık katsayısı .80 'dir.

\section{İşlem}

Ölçeğin Geliştirilme Aşaması: Ölçek maddelerinin hazırlanması sürecinde öncelikle 75 katılımcıdan, "yalan hakkında ne düşündükleri, hangi durumlarda kendi ve başkaları yararına yalan söyledikleri, bu iki yalan türüne ilişkin örnek bir olayı anlatmaları" noktalarından oluşan açık uçlu soru formu ile veri toplanmıştır. Bu verilerin analizi, nitel analiz yöntemlerinden içerik analizi ile yapılmıştır. Analizler 
sonucu, insanların yalan söyleme nedenlerine ilişkin 14 kategori görülmüştür. Oldukça geniş bir yelpazede bulunan bu kategorilerin yanı sıra, madde oluşturma sürecinde giriş kısmında detaylıca aktarılan alan yazından da yararlanılmıştır. Her bir kategori için 5 madde olacak şekilde mevcut ölçek için maddeler hazırlanmıştır. İlk aşamada oluşturulan 70 maddelik ölçek, gelişim psikolojisi ve sosyal psikoloji alanlarında uzman 6 araştırmacıya sunulmuş, uzmanlar maddelerin ölçme açısından uygunluğunu incelemişlerdir. Bu işlemlerin ardından ölçekte 6 maddenin uygun olmadığı sonucuna ulaşılmıştır. Ölçeğin revize edilmiş 64 maddelik formu, dil yapısı ve anlaşılabilirliğini incelemek üzere 30 üniversite öğrencisine verilmiştir. Geri bildirimler doğrultusunda 5 maddenin daha çıkarılmasına karar verilmiştir. Ayrıca, 30 üniversite öğrencisinin ölçeği ortalama tamamlama süresi de belirlenerek bu süre bilgilendirilmiş onam formuna eklenmiştir. Sonuç olarak, geçerlik ve güvenirlik analizleri yapılmak üzere ölçeğin 59 maddelik son hali oluşturulmuştur.

Ölçeğin Uygulanma Aşaması: Yalanın Uygunluğu Ölçeği, her bir katılımcıya bireysel uygulanacak şekilde hazırlanmıştır. COVID-19 salgını nedeniyle eğitim-öğretimin uzaktan yürütülmesi ve kamu ile özel sektörde farklı mesai düzenine geçilmesiyle veri toplama işlemlerinin çevrimiçi platformlar aracılığıyla yapılması tercih edilmiştir. Her bir katılımcının testleri doldurma süresi yaklaşık olarak 20 dakika sürmüştür. Test-tekrar test çalışmasında yer alacak katılımcılardan ölçeğin sonunda ilaveten, bir sonraki çalışma için hatırlayacakları bir rumuz yazmaları istenmiştir. Çalışmanın etik onayı 23.10.2020 tarihli, 183195 sayılı karar ile İstanbul Üniversitesi Sosyal ve Beşeri Bilimler Araştırmaları Etik Kurulundan alınmıştır.

\section{Verilerin Analizi}

Araştırmaya katılan 615 katılımcının yanıtları doğrultusunda, ölçeğin geçerlik ve güvenirlik çalışmaları yapılmıştır. Yalanın Uygunluğu Ölçeği'nin yapı geçerliğini belirlemek için varimax döndürme ile temel bileşenler analizi kullanılarak Açımlayıcı Faktör Analizi (AFA) yapılmıştır.

Yalanın Uygunluğu Ölçeği’nin yapı geçerliğine ilişkin öncelikle, madde analizi sonucu madde-toplam puan korelasyonları .20'nin altında olan maddelerin ölçekten çıkarılması planlanmıştır. Bunun ardından gerçekleştirilen AFA ile örneklem büyüklüğünün uygunluğu, Kaiser-Meyer Olkin (KMO) testi ile incelenmiş; KMO değeri için minimum .70 kriter olarak belirlenmiştir. Örneklem veri dağılımının AFA'ya uygunluğu Bartlett Küresellik testi ile değerlendirilerek bu değerin $p<.001$ düzeyinde anlamlı olması beklenmiştir. Sonraki aşamada ise AFA'da ileri incelemeler gerçekleştirilmiştir. Bu kapsamda ortak varyans değeri .30'un altındaki maddelerin ölçekten çıkarılması sonucu saçılım grafiğinde (scree plot) özdeğeri 1'in üzerinde olan tüm faktörler dikkate alınmış, döndürme öncesi bileşen matrisinde varyansı en fazla açıklayan birinci faktöre faktör yükü .30'un altında yüklenen maddelerin analiz dışı bırakılması planlanmıştır (Büyüköztürk, 2002). Son aşamada ise döndürme sonrası bileşen matrisinde hiçbir faktöre .30 ve üstü faktör yükü ile yüklenmeyen maddeler ile .30 ve üstü faktör yükü ile yüklendiği halde çift faktöre yüklenen maddelerin analiz dışı bırakılması planlanmıştır. Bir maddenin en yüksek faktör yükü ile buna en yakın ikinci faktör yükü arasındaki farkın en az .15 olması çift yüklenme kriteri (Büyüköztürk, 2002) olarak belirlenmiştir. Sözü edilen aşamalar sonrası ilgili kriterlere uyan geriye kalan maddelerle ölçeğin faktör yapısı değerlendirilmiştir.

Güvenirlik analizleri kapsamında, Yalanın Uygunluğu Ölçeği’nin bütününün ve her bir faktörünün iç tutarlılık güvenirliği Cronbach Alpha katsayısı ile hesaplanmıştır. Ölçeğin yakınsak geçerliği ve testtekrar test güvenirliğini belirlemede Pearson Çarpım Momentler Korelasyon Katsayısı kullanılmıştır. Ölçeğin ayırt edici geçerliğini saptamak içinse analizdeki tüm değişkenler normal dağılım gösterdiğinden bağımsız örneklem $t$ testi kullanılmış, sonuçların etki büyüklüğü Cohen d değeri (Cohen, 1988) ile incelenmiştir. Tüm analizler SPSS 20 sürümünde gerçekleştirilmiştir.

\section{BULGULAR}

\section{Geçerlik Analizleri}

\section{Yapı Geçerliği}

Yalanın Uygunluğu Ölçeği'nin yapı geçerliğini incelemek adına ilk olarak madde analizi yapılmış, bu analiz sonucu madde değerlerinin .16 ile .60 arasında değiştiği görülmüştür. Ölçekte .20 değerinin altındaki 6 madde (9., 24., 38., 44., 49., 51.) ölçekten çıkarılmıştır. AFA için faktör çıkarma yöntemi 
olarak temel bileşenler analizi, döndürme tekniği olarak varimax yöntemi kullanılarak ölçeğin yap1 geçerliği test edilmiştir. AFA'da ileri madde incelemelerine geçmeden önce, verilerin faktör analizine uygunluğunu saptamak için incelenen KMO katsayısı ve Bartlett Küresellik testi sonuçlarına göre KMO değeri .91, Bartlett Küresellik testi değeri ise anlamlı bulunmuştur (Bartlett $\chi_{(595)}^{2}=8293.18$, $p<.001)$. Ölçeğin, faktör analizine uygunluğu görüldükten sonraki aşamada maddelerin ortak varyans değeri incelenmiş, .30 altında hiçbir madde olmadığından ölçekten madde çıkarılmamıştır. Ardından döndürme öncesi bileşen matrisi değerleri değerlendirilmiş, varyansı en fazla açıklayan birinci faktöre .30'un altında yüklenen 3 madde $(18 ., 35 ., 46$.$) ölçüm aracından çıkarılmıștır. Son olarak, döndürme$ sonrası bileşen matrisinin incelenmesi sonucu birden fazla faktöre yüklendiği veya .30'un altında faktör yükü olan 15 madde (1., 2., 7., 11., 12., 21., 26., 32., 36., 37., 39., 43., 45., 56., 57.) ölçekten çıkarılmıştır. Ölçeğin son halini oluşturan geriye kalan 35 maddenin faktör yükleri .30'un üzerinde olup toplam altı faktöre yüklenmiştir. Yalanın Uygunluğu Ölçeği’nin faktör yapısına ilişkin bulgular Tablo 2'de verilmiştir. 
Tablo 2. Yalanın Uygunluğu Ölçeğinin Faktör Yapısına Ait Bulgular

\begin{tabular}{|c|c|c|c|}
\hline Faktör/Madde İçerikleri & $\begin{array}{l}\text { Faktör } \\
\text { Yükü }\end{array}$ & $\begin{array}{c}\text { Ortak } \\
\text { Varyans }\end{array}$ & $\begin{array}{l}\text { Madde-Toplam } \\
\text { Puan Korelasyonu }\end{array}$ \\
\hline \multicolumn{4}{|l|}{ Kendini Koruma Yalanlart. Özdeğer=8.8; Varyans=\%25 } \\
\hline 3. Metin evde olmasına rağmen rahatsız edilmek istemediği için kendisini defalarca arayan Kenan'a uygun bir ortamda olmadığını söyledi. & .54 & .56 & .53 \\
\hline $\begin{array}{l}\text { 13. Canan, ödevine yardım etmesi için Başak'ı ısrarlı bir şekilde arayınca Başak, rahatsız edilmek istemediği için işi olmadığı halde bir işi } \\
\text { olduğunu söyledi. }\end{array}$ & 65 & .56 & .58 \\
\hline 17. Özlem mola saatinde alışverişe yalnız gitmek istediği için Fatma'ya eve uğraması gerektiğini söyledi. & 67 & .55 & .55 \\
\hline $\begin{array}{l}\text { 20. Egemen işi olmayan Çetin'e sürekli iş teklif etmesine rağmen Çetin onunla beraber çalışmak istemediği için bir yerde işe başladığını } \\
\text { söyledi. }\end{array}$ & .62 & .44 & .52 \\
\hline 31. Hülya, önceki gün gittiği yeri söylemek istemediği için, Demet'e evde uyuduğunu söyledi. & 66 & 60 & 61 \\
\hline 40. Baran, Selim'e akşam ne yapacağını sorduğunda arkadaşlarıyla dışarı çıkacağını söylemek istemeyen Selim ders çalışacağını söyledi. & .59 & .56 & .60 \\
\hline 47. Fidan, kendisinden borç isteyen Eda'nın aldığı parayı geri ödemeyeceğini düşündüğü için ona parasının olmadığını söyledi. & .56 & .44 & .44 \\
\hline $\begin{array}{l}\text { 52. Yalnız kalmak isteyen Nilay, arkadaşlarıyla buluşmaya gelmesi için kendisine baskı yapan Seher'e, hasta olmadığı halde hasta olduğunu } \\
\text { söyledi. }\end{array}$ & .71 & .58 & 62 \\
\hline 59. Serdar, istemediği bir yere kendisini 1srarla çağıran Erhan'a herhangi bir işi olmadığı halde işi olduğu için gelemeyeceğini söyledi & .71 & .62 & 63 \\
\hline \multicolumn{4}{|l|}{ İmaj Yönetimi Yalanları. Özdeğer=3.6; Varyans=\%10.4 } \\
\hline 16. Faruk, kendisini iyi göstermek için öyle olmadığı halde Tufan’a uluslararası turnuvada madalya aldığını söyledi. & .71 & .50 & .34 \\
\hline 23. Gaye, Cem'i etkilemek için öyle olmadığı halde babasının çok saygın bir iş adamı olduğunu söyledi. & .79 & .64 & .35 \\
\hline 28. Çağrı, İhsan’ın merak ettiği kitabı duymamış olmasına rağmen bilgili görünmek için kitabın çok iyi olduğunu söyledi. & .61 & .48 & .39 \\
\hline 34. Erol, işinde daha iyi bir pozisyona yükselmek için yapmadığı şeyleri yöneticisine kendisi yapmış gibi anlattı. & .65 & .54 & .34 \\
\hline 41. Tuğba, hiçbir başarısı olmamasına rağmen kendisini olduğundan iyi göstermek için Ayla’ya geçmişinde birçok ödül aldığını söyledi. & .81 & .68 & .34 \\
\hline 55. Tayfun, geçimini zor sağlamasına rağmen Ferhat'a mahcup olmamak için lüks bir hayatı olduğunu söyledi. & .68 & .55 & .38 \\
\hline
\end{tabular}


Tablo 2 devam. Yalanın Uygunluğu Ölçeğinin Faktör Yapısına Ait Bulgular

Prososyal Yalanlar. Özdeğer=2.6; Varyans $=\% 7.5$

8. Sema, Esra'yı mutlu etmek için, izlemek istemediği halde filmi çok merak ettiğini söyledi.

22. Vedat, dışarı çıkmayı hiç istemese de kendisine dışarı çıkmayı teklif eden Aydın'a severek geleceğini söyledi.

.66

.57

.37

27. Duygu, Ayşe'nin mutlu olması için, aslında sevmediği bir etkinliğe katılmayı istediğini söyledi.

30. Serhat, Berk ile otururken sıkılmış olmasına rağmen sohbetten keyif aldığını söyledi.

48. İrem, Pınar'ın hazırlamış olduğu yemekleri hiç sevmemesine rağmen çok sevdiğini söyledi.

53. Burak, Eser'in üzülmemesi için iyi bir iş çıkarmamasına rağmen Eser'e başarılı olduğunu söyledi.

58. Hande, aslında hiç beğenmese de Aslı'ya yeni saç modelinin çok yakıştığını söyledi.

6. Selda, evliliği hakkında soru soran arkadaşı Gizem'e yaşadığı problemlerin aile içinde kalmasını istediği için her şeyin yolunda olduğunu söyledi.

10. İsmail, patronuyla sorun yaşıyor olmasına rağmen, Sedat işini sorunca konuyu geçiştirmek için işinde mutlu olduğunu söyledi.

$.62 \quad .50 \quad .41$

15. Gül, kendisinin nasıl olduğunu soran Dilara'ya o dönem boğuştuğu sorunları anlatmayıp konuyu geçiştirmek istediği için iyi olduğunu söyledi.

42. Sezen, ilişkisinin nasıl gittiğini soran Buket'e, erkek arkadaşıyla yaşadığı problemleri saklamak için ilişkisinin gayet iyi gittiğini söyledi.

50. Dilek'in kendisini anlamayacağını düşünen Nagihan, üzgün olmasına rağmen boşuna uğraşmamak için her şeyin yolunda olduğunu söyledi.

Zorunlu Yalanlar. Özdeğer=1.4; Varyans=\%3.9

19. Aylin sigara içtiği halde korktuğu için ailesine içmediğini söyledi.

25. Gülay, arkadaşlarıyla tatile gidebilmek için ailesine eğitime katılacağını söyledi.

33. Erkek arkadaşıyla gizlice buluşan Sevgi'nin ricası üzerine, Hilal onun ailesine Sevgi’nin kendi yanında olduğunu söyledi.

$\begin{array}{lll}.63 & .58 \quad .48\end{array}$

54. Özge'nin ailesi kızlarına ulaşamayınca onun nerede olduğunu Büşra’ya sordular ve Büşra arkadaşının partide olmasına rağmen kütüphanede olduğunu söyledi.

\section{Araçsal Yalanlar. Özdeğer $=1.1$; Varyans $=\% 3.1$}

4. Arda iş mülakatında işe kabul edilmek için kullanmayı bilmediği programları bildiğini söyledi.

5. Osman yöneticisinin verdiği işi yapmak istemediği için öyle olmadığı halde ona hastane randevusu olduğunu söyledi.

$.56 \quad .51$

14. Hatasından dolayı Fatih'in işini kaybetmemesi için, Tolga yöneticiye Fatih'in hatalı olmadığını söyledi.

29. Ceren, sınavda arkadaşından kopya çektiği halde dersten kalmamak için hocasına kopya çekmediğini söyledi.

$\begin{array}{lll}.61 & .48 & .50 \\ .73 & .70 & .44 \\ .76 & .68 & .53 \\ .73 & .67 & .52 \\ \end{array}$


Ölçeğin son hali, Tablo 2'de de görüldüğü üzere özdeğeri 1'in üzerinde olan ve toplam varyansın \%54.5'ini açıklayan altı faktörlü bir yapı göstermiştir. Varyansın \%25'ini açıklayan ve 9 maddeden oluşan birinci faktör "kendini koruma yalanları"; varyansın \%10.4'ünü açıklayan ve 6 maddeden oluşan ikinci faktör "imaj yönetimi yalanları"; varyansın \%7.5'ini açıklayan ve 7 maddeden oluşan üçüncü faktör "prososyal yalanlar"; varyansın \%4.6'sını açıklayan ve 5 maddeden oluşan dördüncü faktör "geçiştirme yalanları"; varyansın \%3.9'unu açıklayan ve 4 maddeden oluşan beşinci faktör "zorunlu yalanlar"; varyansın \%3.1'ini açıklayan ve 4 maddeden oluşan altıncı faktör ise "araçsal yalanlar" olarak adlandırılmıştır.

\section{Yakınsak Geçerlik}

Ölçeğin yakınsak geçerliği, aynı yapıyı ölçtüğü düşünülen Dürüstlük Ölçeğinin Yalan Söyleme Boyutu ile korelasyonlarına bakılarak incelenmiştir. Sonuçlar, Tablo 3 'te gösterilmiştir.

Tablo 3. Yalanın Uygunluğu Ölçeği ile Dürüstlük Ölçeğinin Yalan Söyleme Boyutu Arasındaki Korelasyon Değerleri

\begin{tabular}{lc}
\hline & $\begin{array}{c}\text { Dürüstlük Ölçeği } \\
\text { Yalan Söyleme Boyutu }\end{array}$ \\
\hline Yalanın Uygunluğu Ölçeği-Toplam & $.53^{*}$ \\
Kendini Koruma Yalanları & $.48^{*}$ \\
İmaj Yönetimi Yalanları & $.20^{*}$ \\
Prososyal Yalanlar & $.23^{*}$ \\
Geçiştirme Yalanları & $.28^{*}$ \\
Zorunlu Yalanlar & $.47^{*}$ \\
Araçsal Yalanlar & $.48^{*}$ \\
\hline
\end{tabular}

$* p<.01$

Tablo 3'te de görüldüğü üzere Yalanın Uygunluğu Ölçeği'nin tamamı ve alt boyutları, Dürüstlük Ölçeği'nin Yalan Söyleme Boyutu ile beklendiği gibi pozitif yönde anlamlı ilişkiler göstermektedir. Dolayısıyla genel olarak yalanın ve onun alt boyutlarındaki her bir yalan türünün uygun bulunmasındaki artış, yalan söylemedeki artışla paralel bir şekilde ilerlemektedir.

\section{Ayırt Edici Geçerlik}

Ölçeğin ayırt edici geçerliğini belirlemek adına Dürüstlük Ölçeği’nin Yalan Söyleme Boyutundan alınan toplam puana göre alt ve üst $\% 27$ 'lik dilimlere düşen katılımcılar yalan söyleme puanı yüksek ( $n=174$; 20 puan ve üstü; imaj yönetimi alt boyutu için $n=167)$ ve düşük $(n=172 ; 13$ puan ve alt1; imaj yönetimi alt boyutu için $n=169$ ) olmak üzere iki gruba ayrılmıştır. Bu iki grubun Yalanın Uygunluğu Ölçeğinden aldıkları puanları karşılaştırmak adına yapılan bağımsız örneklem $t$ testi sonuçları Tablo 4'tedir. 
Tablo 4. Dürüstlük Ölçeği Yalan Söyleme Boyutuna Göre Düşük ve Yüksek Düzeyde Yalan Söyleyen Grubun Yalanı Uygun Bulma Puanlarına Ait Ortalama, Standart Sapma ve Test İstatistiği Değerleri

\begin{tabular}{|c|c|c|c|c|c|}
\hline & $\begin{array}{l}\text { Dürüstlük Ölçeği } \\
\text { Yalan Söyleme } \\
\text { Boyutu Grubu }\end{array}$ & $\mathrm{N}$ & Ort. & SS & $\mathrm{t}$ \\
\hline \multirow[t]{2}{*}{ Yalanın Uygunluğu Ölçeği-Toplam } & Düşük & 172 & 82.11 & 17.65 & $-12.84 *$ \\
\hline & Yüksek & 174 & 104.98 & 15.37 & \\
\hline \multirow[t]{2}{*}{ Kendini Koruma Yalanları } & Düşük & 172 & 22.04 & 7.13 & $-11.85^{*}$ \\
\hline & Yüksek & 174 & 30.63 & 6.32 & \\
\hline \multirow[t]{2}{*}{ İmaj Yönetimi Yalanları } & Düşük & 169 & 7.95 & 2.57 & $-4.70 *$ \\
\hline & Yüksek & 167 & 9.40 & 3.04 & \\
\hline \multirow[t]{2}{*}{ Prososyal Yalanlar } & Düşük & 172 & 20.73 & 5.73 & $-4.26^{*}$ \\
\hline & Yüksek & 174 & 23.14 & 4.77 & \\
\hline \multirow[t]{2}{*}{ Geçiştirme Yalanları } & Düşük & 172 & 16.38 & 3.97 & $-5.95^{*}$ \\
\hline & Yüksek & 174 & 18.72 & 3.30 & \\
\hline \multirow[t]{2}{*}{ Zorunlu Yalanlar } & Düşük & 172 & 7.36 & 3.13 & $-11.77 *$ \\
\hline & Yüksek & 174 & 11.68 & 3.67 & \\
\hline \multirow[t]{2}{*}{ Araçsal Yalanlar } & Düşük & 172 & 7.37 & 2.31 & $-12.13^{*}$ \\
\hline & Yüksek & 174 & 10.75 & 2.83 & \\
\hline
\end{tabular}

$* p<.001$

Yalanın Uygunluğu Ölçeği Toplam Puanı ile İmaj Yönetimi Yalanları ve Geçiştirme Yalanları faktörlerindeki iki grubun karşılaştırılmasında, varyansların homojenliğinin ihlal edildiği durumdaki serbestlik derecelerine bağlı kalınarak anlamlılık değerleri yorumlanmıştır (Levene testi sonucuna göre varyansların homojenliği varsayımı Yalanın Uygunluğu Ölçeği Toplam Puanı için $\mathrm{F}(336.51)=6.30, p$ $=0.012$, İmaj Yönetimi Yalanları için F(323.55) = 7.62, $p=0.006$, Geçiştirme Yalanları için F(331.42) $=6.75, p=0.01$ ihlal edilmiştir). Bu sonuçlara göre düşük yalan söyleme grubundaki katıllımcılar, yüksek yalan söyleme grubundaki katılımcılardan hem toplamda hem de tüm alt boyutlarda yalanı anlamlı olarak daha az uygun bulmuşlardır (Tablo 4'teki sırasıyla $t(336.5)=-12.84, d=1.38 ; t(344)=-$ $11.85, d=1.27 ; t(323.5)=-4.7, d=0.51 ; t(344)=-4.26, d=0.45 ; t(331.4)=-5.95, d=0.64 ; t(344)=-$ $11.77, d=1.26 ; t(344)=-12.13, d=1.30$; tümü için $p<.001)$. Bulgular, Yalanın Uygunluğu Ölçeğinin düşük ve yükssek düzeyde yalan söyleyen grubun yalanı uygun bulma puanlarındaki farklılığı ayırt edebildiğini göstermektedir.

\section{Güvenirlik}

Ölçeğin altı faktörlü son hali ile yürütülen güvenirlik analizi kapsamında ilk olarak iç tutarlılık katsayıları hesaplanmıştır. Analizler sonucunda görülen Cronbach Alpha katsayıları tüm ölçek için .91 iken, alt boyutlar için .64 ile .87 arasında değişmektedir. Ölçeğin test-tekrar test güvenirliği kapsamında 58 kişiden oluşan ve üç hafta ara ile yapılan test-tekrar uygulamalarına ilişkin korelasyon sonuçları ise .88 ile .98 arasında yüksek düzeyde anlamlı ilişkiler göstermiştir. İlgili tüm değerler Tablo 5 'te gösterilmiştir.

Tablo 5. Yalanın Uygunluğu Ölçeğinin İç Tutarlık ve Test-Tekrar Test Güvenirlik Analizi Sonuçları

\begin{tabular}{lcccc}
\hline & Ort. & SS & İç tutarlık & Test-tekrar test \\
\hline Yalanın Uygunluğu Ölçeği-Toplam & 93.42 & 18.73 & .91 & $.98^{*}$ \\
Kendini Koruma Yalanları & 26.36 & 7.55 & .87 & $.96^{*}$ \\
İmaj Yönetimi Yalanları & 9.00 & 3.53 & .84 & $.92^{*}$ \\
Prososyal Yalanlar & 21.96 & 5.31 & .82 & $.92^{*}$ \\
Geçiştirme Yalanları & 17.59 & 3.79 & .78 & $.97^{*}$ \\
Zorunlu Yalanlar & 9.59 & 3.89 & .81 & $.96^{*}$ \\
Araçsal Yalanlar & 8.93 & 2.85 & .64 & $.88^{*}$ \\
\hline
\end{tabular}

$* p<.01$ 


\section{TARTIŞMA}

Çalışmanın amacı, Türkiye'de yaşayan üniversite öğrencileri ve yetişkinlerin farklı nedenlerle söylenen yalanları ne düzeyde uygun bulduklarını incelemek ve buna yönelik geliştirilen "Yalanın Uygunluğu Ölçeğinin" geçerlik-güvenirlik çalışmasını gerçekleştirmektir. Analizler, bu testin geçerlik ve güvenirliği açısından yeterli psikometrik özelliklere sahip olduğunu göstermiştir. Ölçeğin yapı geçerliğine ilişkin analizler incelendiğinde, altı faktörlü bir yapının ortaya çıktığı görülmektedir. Analizler sonucunda elde edilen faktörler "kendini koruma yalanları", "imaj yönetimi yalanları", "prososyal yalanlar", "geçiştirme yalanları", "zorunlu yalanlar" ve "araçsal yalanlar" şeklindedir.

Yalanın Uygunluğu Ölçeğinin yakınsak geçerliğini belirlemek amacıyla yalanın uygun bulunmasıyla ilişkili olması beklenen Dürüstlük Ölçeğindeki Yalan Söyleme Boyutundan yararlanılmıştır. Bulgular, "Yalanın Uygunluğu Ölçeğinin” toplam puanıyla Dürüstlük Ölçeğinin Yalan Söyleme Boyutunun pozitif yönde ve iyi düzeyde korelasyona sahip olduğunu göstermiştir. Alt boyutlar değerlendirildiğinde, benzer şekilde pozitif ve anlamlı düzeyde ilişkiler olduğu görülmektedir. Bu sonuçlar, ölçeğin yakınsak geçerlik açısından uygun olduğuna işaret etmektedir.

Ölçeğin test-tekrar test güvenirlik ve iç-tutarlılık katsayılarının yüksek olması da test edilen yapının güvenirliğini ortaya koymuştur. Ölçeğin test-tekrar test güvenirlik katsayılarının oldukça iyi düzeyde olması ölçme aracının güvenirliğine işaret etmektedir. Alt boyutların iç tutarlılık katsayılarına bakıldığında değerlerin istenilen düzeyde olduğu, araçsal yalan alt boyutunun iç tutarlılık katsayısının ise .64 olduğu bulunmuştur. Söz konusu değer görece düşük olmakla birlikte yine de kabul edilebilir sınırlar içerisinde olduğu görülmektedir (Schermelleh-Engel, Moosbrugger ve Müller, 2003). Yine de bu noktada, gelecek çalışmaların daha heterojen bir katılımcı grubu ile gerçekleştirilmesi önerilebilir.

Ölçeğin geçerlik analizleri sonucunda ortaya çıkan ve varyansı en çok açıklama yüzdesine sahip olan ilk faktör "kendini koruma yalanları" olmuştur. Bu faktördeki maddeler değerlendirildiğinde, insanların kendi yapmak istediklerinin aksi bir durum olduğunda, mahremiyet ve özerkliklerini korumak amaçl1 söyledikleri yalanların bir arada olduğu görülmektedir. İnsanların rahatsız edilmemek, kendilerinin istemediği bir şeyi yapmamak ve gerçeği saklamak için yalan söyledikleri maddeler bu faktörün altında toplanmıştır. Alan yazın incelendiğinde, mevcut çalışmadan elde edilen bu sonuç yalan konusunda önemli çalışmaları bulunan Ekman'ın (2016) insanların gizlilik ve mahremiyetlerini korumak amacıyla yalan söyledikleri şeklindeki açıklamalarını desteklemektedir. DePaulo, Ansfield, Kirkendol ve Boden'in (2004) araştırmasında da kendini koruma şeklinde benzer bir yalan söyleme motivasyonu olduğu göze çarpmaktadır. Bu açıdan yalanın uygunluğu konusunda ortaya çıkan bu faktörün yalan söyleme motivasyonlarını çalışan araştırmacıların bulgularıyla uyumlu olduğu söylenebilir.

"İmaj yönetimi yalanları" olarak isimlendirilen bir sonraki faktör ise insanların etkileşim sırasında kendilerini olduklarından daha iyi gösterme ihtiyacı hissettikleri durumlarda ve başkalarının gözünde küçük düşmelerini önleyeceklerini düşündüklerinde yalan söylemeye başvurduklarını ifade etmektedir. İmaj koruma yalanlarına ilişkin maddeler incelendiğinde, insanların kendi-yönelimli bir motivasyonla bu tür yalanları kullanabilecekleri anlaşılmaktadır. İnsanlar için diğerlerinin onları nasıl gördüklerinin benlik yapılanmasındaki önemi, özellikle sembolik etkileşim geleneğinde önemli bir yer tutmaktadır (bkz. Cooley, 1902; Mead, 1934). Dolayısıyla insanlar, sosyal etkileşim esnasında kendilerini izleyerek olumlu imaj yaratmak adına farklı stratejilerle benlik sunumu gerçekleştirebilmekte ve diğerlerinin kendilerine yönelik izlenimlerini yönetme ihtiyacı duyabilmektedirler (Goffman, 1967; Brown ve Levinson, 1987). Buna bağlı olarak etkileşim ortamında yalan söyleme, bu ihtiyaca paralel olarak kendini göstermektedir. Gündelik hayatta da bu türden olumlu bir izlenim bırakmak, saygı görmek gibi psikolojik kazanç sağlayan yalanların, en az maddi kazanım sağlayan yalanlar kadar yaygın olduğu görülmektedir (DePaulo, Kashy, Kirkendol, Wyer ve Epstein, 1996). Dolayısıyla bu çalışmada varyansı ikinci en iyi açıklayan bu faktör, Türkiye örnekleminde de önemli görülerek kendine yer bulmuştur.

Geçerlik analizleri sonucunda elde edilen faktörlerden biri prososyal yalanlar olmuştur. Sonuçlar, Türkiye'deki insanların bir başkasını kırmamak, üzmemek ya da en genel haliyle başkalarının iyioluşunu devam ettirmek adına söylenen "prososyal yalanları" benzer bir noktada uygun gördüklerine işaret etmektedir. Bu tür yalanlar, aslında birçok araştırmada yalanı söyleme davranışlarının ana 
boyutlardan biri olarak ifade edilmektedir (Örn., Aydın, 2020; DePaulo ve ark., 1996; DePaulo ve ark., 2004). Mevcut çalışmada da insanların nezaket ve başkalarının iyi-oluşuna hizmet etme amacıyla söyledikleri yalanlar ayrı bir faktör olarak değerlendirilmiştir. $\mathrm{Bu}$ sonuç, alan yazındaki yalan sınıflandırmalarını destekler niteliktedir.

Yalanın uygunluğu konusunda ortaya çıkan bir diğer faktör "geçiştirme yalanları" şeklindedir. Bu faktör, insanların başkalarıyla etkileşimleri sırasında konuşmak istemedikleri konular olduğunda, bunların üstünü kapatarak konuyu değiştirmek amacıyla söylenen "geçiştirme yalanlarına" başvurmayı uygun bulabildiklerine işaret etmektedir. Geçiştirme yalanlarının yer aldığı maddeler, DePaulo ve arkadaşlarının $(1996 ; 2004)$ küçük yalan kategorisine benzer şekilde, sonuçları açısından büyük önem taşımayan ve başkalarına zarar vermeyen ifadelerdir. Bryant'ın (2008) yalan sınıflandırmasına ilişkin gerçekleştirmiş olduğu çalışmada da benzer bir şekilde, önemsiz olan ve gerçeği kıvırma, esnetme amaçlı yalanların bir kategoride toplandığı görülmektedir. Mevcut çalışmada yalanın uygunluğu konusunda elde edilen geçiştirme yalanlarının da bu araştırmacıların kategorizasyonuyla benzerlikler taşıdı̆̆ 1 ifade edilebilir.

“Zorunlu yalanlar”, analiz sonuçları incelendiğinde elde edilen diğer bir faktördür. İlgili maddeler değerlendirildiğinde bunların, yalan söylenmediği takdirde sonucu açısından çok fazla olumsuzluk barındırmasının ve yalancının cezalandırılmasının muhtemel olduğu, dolayısıyla da yalan söyleyenin bu davranış1 kendisine deyim yerindeyse hak gördüğü türden yalanlar olduğu görülmektedir. Bryant'in (2008) yalan sınıflandırmasına bakıldığında kişinin kendi yararına olan beyaz yalanlar, başkası yararına olan beyaz yalanların yanında gri yalanlar da söz konusudur. Gri yalanın alt boyutlarından biri sınırları belli olmayan durumlarda katılımcıların mecburen yalan söylenmesi gerektiğini ifade ettikleri "meşru gri yalanlardır". Aslında gri yalanın bu boyutu mevcut çalışmada görülen faktörle uyumlu görünmektedir. Ayrıca DePaulo ve arkadaşlarının (2004) çalışmasında da yalancının yalan söylemeyi kendisinde hak gördüğü türden bir yalan motivasyonunun olduğu rapor edilmiştir. Mevcut çalışmadaki maddeler de bunlara benzer şekilde katılımcılar tarafından yalan söyleyen kişi için zorunluluk olarak algılanabileceği gerekçesiyle bu şekilde isimlendirilmiştir.

Ölçeğin geçerlik analizleri sonucunda karşımıza çıkan son faktör ise araçsal yalanlar olmuştur. Bu faktördeki maddelerin ise insanların herhangi bir konuda çıkar elde etmek, kazanç sağlamak için söylenen yalanlar ile ilişkili olduğu görülmektedir. Avantaj sağlamak için söylenen bu tür yalanlara çocukluk döneminden itibaren rastlandığı (Aydın, Dayhan, Eskicioğlu, Karabacak ve Karakaş, 2020; Lavoie, Yachison, Crossman ve Talwar, 2017), yetişkinlik döneminde de yaygın bir motivasyon olarak karşımıza çıktığı (Heyman, Hsu, Fu ve Lee, 2013) bilinmektedir. Bu faktördeki bir maddenin başkasının işini kaybetmemesi için söylenen türde yalan olması ilk bakışta farklılık gibi değerlendirilebilir. Ancak söz konusu maddenin başkası da olsa avantajı kaybetmeme motivasyonu şeklinde algılanmış ve yorumlanmış olması mümkündür. Dolayısıyla bu maddenin araçsal yalan kategorisine girmiş olması anlamsız durmamaktadır. DePaulo ve arkadaşlarının (2004) çalışmasında ortaya çıkan araçsal yalan boyutu, araştırmacılar tarafından maddi bir ödüle, kişisel zevkler veya avantajlar elde etme amacıyla söylenen yalanlar şeklinde ifade edilmiştir. Mevcut çalışmanın analizleri sonucunda benzer bir faktör çıkması da bu yönden alan yazına uygun düşmektedir.

Sonuçlar incelendiğinde, Türkiye'deki üniversite öğrencileri ve yetişkinlerin yalanı uygun bulma konusunda kendini koruma amacıyla söylenen yalanların en yüksek ortalamaya sahip olduğu görülmektedir. Bu kategoriyi prososyal yalanların takip ettiği görülmekteyken, en az uygun bulunan yalanlar ise araçsal yalanlar ve imaj yalanları olmuştur. Özetle katılımcılar, bir yandan özerkliklerini tehdit eden ve kişiler arası ilişkilerinde diğerlerini gözeten durumlarda yalanı uygun görerek özerklik ve ilişkiselliklerini aynı anda koruma eğilimi göstermişlerdir. Bununla beraber katılımcılar, özerklikle alakasız olan ve kişiler arası ilişkilerde kişinin kendi çıkarına hizmet eden yalanları da daha az uygun görerek ilişkiselliği tehdit etme potansiyeli olan durumları onaylamamışlardır. Dolayısıyla bu sonuçlar, Türkiye toplumunu özerk ve ilişkisel bir bağlamda ele alan yaklaşımlarla (İmamoğlu, 2002; Kağıtçıbaşı, 1996; Karadayı, 1998) paralel gözükmektedir.

Elde edilen bulgular doğrultusunda, ilerideki araştırmalar için bazı önerilerde bulunmak mümkündür. Farklı türlerdeki yalanların uygun bulunmasına ilişkin çeşitli sosyal ve kültürel etmenlerin rolü olduğu düşünülebilir. Örneğin, Schwartz ve Bilsky (1990) tarafından öne sürülen toplumsal değerler açısından 
bakıldığında, özaşkınlık boyutunda yer alan evrenselcilik ve iyilikseverlik değerlerine sahip olan bireylerin, başkalarının yararını daha fazla gözettiği bilinmektedir. Dolayısıyla, bu değerlere önem verenlerin başkalarının yararına söylenen yalanları daha fazla kabul edilebilir bulması beklenebilir. Yine benzer bir noktadan hareketle, yalanın kabul edilebilirliği konusunda yurt dışında birçok çalışma gerçekleştirilmiş olmasına karşın (Örn., Park, Choi, Oh ve Levine, 2018), ülkemizde böyle bir çalışmaya rastlanılmaması nedeniyle bireycilik-toplulukçuluk karşılaştırmaları üzerinden araştırmaların yürütülmesi faydalı olabilir. Hatta bu çalışmadan elde edilen sonuca göre, katılımcıların en fazla uygun buldukları yalanların başkası yararına söylenen ve kendini koruma amacıyla söylenen yalanlar olduğu düşünülürse bu konuda yapılacak çalışmalar yeni araştırmaların kapısını aralayabilir.

Bu konuda yapılabilecek bir başka çalışma konusu ise farklı kişilik özelliklerine sahip bireylerin hangi tür yalanları uygun bulduklarını incelemek olabilir. Yalanın uygun görülmesi konusunda birçok faktörün elde edilmesi, kişilik özelliklerinin bu değişkenle bağlantılarının araştırılmasını da mümkün kılacaktır. Kişilik araştırmalarında yaygın olarak kullanılan 5 faktörlü "OCEAN" modelinin yanında, Dürüstlük-Alçakgönüllülük boyutunu içeren 6 faktörlü bir modelle çalışmaların devam ettiği görülmektedir (Ashton, Lee ve De Vries, 2014). Bu nedenle, farklı yaklaşımlardan yararlanarak kişilik özelliklerinin hangi tür yalanların uygun bulunmasıyla ilişkili olduğu problemini araştırmak yerinde olabilir.

Mevcut çalışma sonucunda elde edilen faktörler doğrultusunda, insanların farklı türlerdeki yalanları uygun bulma düzeylerinin yalan söylenen kişiye göre değişip değişmediği ileride yapılacak araştırmalarda incelenebilir. Arkadaşlık ilişkileri, grup dinamikleri (iç-grup, grup aidiyeti gibi), aile üyeleri, otorite/amir/patron gibi yalanın alıcısı konumundaki kişilerin manipüle edilerek yalanın uygunluğunun değerlendirilmesi alan yazın açısından faydalı olabilir.

Çalışma birçok açıdan alana katkı sunmakla birlikte, bazı sınırlılıklara da sahiptir. Çalışmanın en önemli sınırlılığı katılımcı grubunun özelliklerinden kaynaklanmaktadır. Özellikle kadın katılımcıların, üniversite öğrencilerinin, kendilerini orta gelir düzeyinde algılayan katılımcıların ve bekar katılımcıların sayısının fazla oluşu bulguları genellemeye engel olmaktadır. Ayrıca katılımcıların büyük çoğunluğunun büyükşehirlerde yaşıyor olması, daha küçük yerleşim yerlerinde yaşayan yetişkinlerin yalana ilişkin yargılarının anlaşılmasını güçleştirmektedir. Yalan söyleme nedenleri konusunda önemli çalışmalar sunan DePaulo ve meslektaşları (1996), farklı örneklem gruplarında çeşitli demografik değişkenler açısından farklılaşan gruplarda insanların yalan söyleme davranışlarını incelemiş ve çalışmaları sonucunda farklı grupların çok büyük ölçüde benzerlik gösterdiğini raporlamışlardır. Her ne kadar, burada sayılan demografik değişkenler çok kritik görünmese de, ülkemizde yapılacak araştırmalarda daha homojen bir grupla bu çalışmanın tekrar edilmesi, farklı bir kültürde söz konusu durumun etkisini görmek açısından faydalı olacaktır.

Sonuç olarak, "Yalanın Uygunluğu Ölçeğinin" ülkemizde yapılacak araştırmalarda üniversite öğrencileri ve yetişkinlerin hangi tür yalanları uygun bulduklarını değerlendirme konusunda kullanılabilecek, geçerlik ve güvenirliği olan faydalı bir ölçme aracı olduğu söylenebilir. Ayrıca bu testin Türkiye ile benzer toplumsal yapıya sahip ülkelerdeki araştırmacılar tarafından yapılacak uyarlama çalışmaları, yalan konusunda çalışan araştırmacılara farklı kültürlerden gelen bulguları sunmak açısından önem taşımaktadır. 


\section{KAYNAKLAR}

Ashton, M. C., Lee, K. ve De Vries, R. E. (2014). The HEXACO Honesty-Humility, Agreeableness, and Emotionality factors: A review of research and theory. Personality and Social Psychology Review, 18(2), 139-152.

Aydın, M. Ş. (2020). Yalanın renkleri: Yalanın tanımlanması ve türleri üzerine bir değerlendirme. Uluslararası Sosyal Araştırmalar Dergisi, 13(69), 712-720.

Aydın, M. Ş., Dayhan, T., Eskicioğlu, G., Karabacak, A. ve Karakaş, E. (2020). 3-5 Yaş çocuklarında zihin kuramı ve yönetici işlev becerilerinin olumsuz ve prososyal yalan söyleme davranışları üzerindeki etkisi. Çocuk ve Gelişim Dergisi, 3(5), 47-60.

Bilgiç, R., Bıkmaz, Ö., Esgin, E. ve Şahin, G. S. (2011). İşe alım sürecinde kullanılacak dürüstlük ölçeği oluşturma çalışması. Türk Psikoloji Yazıları, 14(27), 80-85.

Bok, S. (1978). Lying: Moral choice and private and public life. Hassocks, UK: Harvester Press.

Brown, P. ve Levinson, S. (1987). Politeness: Some universals in language usage. Cambridge, UK: Cambridge University Press.

Bryant, E. M. (2008). Real lies, white lies and gray lies: Towards a typology of deception. Kaleidoscope: A Graduate Journal of Qualitative Communication Research, 7, 23-48.

Büyüköztürk, Ş. (2002). Sosyal bilimler için veri analizi el kitabı. Pegem A Yayıncılık.

Cantarero, K., Szarota, P., Stamkou, E., Navas, M. ve Dominguez Espinosa, A. D. C. (2018). When is a lie acceptable? Work and private life lying acceptance depends on its beneficiary. The Journal of Social Psychology, 158(2), 220-235.

Choi, H. J., Park, H. S. ve Oh, J. Y. (2011). Cultural differences in how individuals explain their lying and truth-telling tendencies. International Journal of Intercultural Relations, 35(6), 749-766.

Cohen, J. (1988). Statistical power analysis for the behavioral sciences (2. Bask1). Hillsdale, NJ: Erlbaum.

Cooley, C, H. (1902). Human nature and social order. New York: Scribner's.

DePaulo, B. M., Ansfield, M. E., Kirkendol, S. E. ve Boden, J. M. (2004). Serious lies. Basic and Applied Social Psychology, 26(2-3), 147-167.

DePaulo, B. M., Kashy, D. A., Kirkendol, S. E., Wyer, M. M. ve Epstein, J. A. (1996). Lying in everyday life. Journal of Personality and Social Psychology, 70, 979-995.

Ekman, P. (2016). Çocuklar neden yalan söyler? (Ç. Dirhemsiz, çev.). İstanbul: Yakamoz Yayınları.

Evans, A. D. ve Lee, K. (2013). Lying, morality, and development. Handbook of Moral Development, $361,361-384$.

Fu, G., Evans, A. D., Wang, L. ve Lee, K. (2008). Lying in the name of the collective $\quad$ good: $\quad$ A developmental study. Developmental Science, 11(4), 495-503.

Fu, G., Lee, K., Cameron, C. ve Xu, F. (2001). Chinese and Canadian adults' categorization and evaluation of lie- and truth-telling about prosocial and antisocial behaviors. Journal of CrossCultural Psychology, 32, 720-727.

Fu, G., Xu, F., Cameron, C., Heyman, G. ve Lee, K. (2007). Cross-cultural differences in children's choices, categorizations, and evaluations of truths and lies. Developmental Psychology, 43, 278293.

Goffman, E. (1967). Interaction ritual: Essays on face-to-face behavior. New York: Anchor.

Heyman, G. D., Hsu, A. S., Fu, G. ve Lee, K. (2013). Instrumental lying by parents in the US and China. International Journal of Psychology, 48(6), 1176-1184.

İmamoğlu, E. O. (2002). Doğu-Batı kavşă̆ında benlik: Dengeli ayrışma-bütünleşme modeli. 12. Psikoloji Kongresinde Sunulan Bildiri, Orta Doğu Teknik Üniversitesi, Ankara. 
Kağıtçıbaşı, Ç. (1996). Özerk-ilişkisel benlik: Yeni bir sentez. Türk Psikoloji Dergisi, 11(37), 36-43.

Kağıtçıbaşı, Ç. (2005). Autonomy and relatedness in cultural context: Implications for self and family. Journal of Cross-Cultural Psychology, 36(4), 403- 422.

Karadayı, E. F. (1998). İlişkili özerklik-kavramı, ölçülmesi, gelişimi, toplumsal önemi, gençlere ve kültüre özgü değerlendirmeler. Adana: Çukurova Üniversitesi Yayınları.

Lavoie, J., Yachison, S., Crossman, A. ve Talwar, V. (2017). Polite, instrumental, and dual liars: Relation to children's developing social skills and cognitive ability. International Journal of Behavioral Development, 41(2), 257-264.

Lee, K., Cameron, C. A., Xu, F., Fu, G. ve Board, J. (1997). Chinese and Canadian children's evaluations of lying and truth telling: Similarities and differences in the context of pro and antisocial behaviors. Child Development, 68, 924-934.

Lee, K., Xu, F., Fu, G. ve Chen, S. (2001). Taiwan and mainland Chinese and Canadian children's categorization and evaluation of lie-and truth-telling: A modesty effect. British Journal of Developmental Psychology, 19, 525-542.

Levine, T. R. (2014). Truth-default theory (TDT): A theory of human deception and deception detection. Journal of Language and Social Psychology, 33, 378-392.

McCornack, S. A., Morrison, K., Paik, J. E., Wisner, A. M. ve Zhu, X. (2014). Information manipulation theory 2: A propositional theory of deceptive discourse production. Journal of Language and Social Psychology, 33(4), 348-377.

Mead, G. H. (1934). Mind, self, and society. Chicago: University of Chicago Press.

Oliveira, C. M. ve Levine, T. R. (2008). Lie acceptability: A construct and measure. Communication Research Reports, 25(4), 282-288.

Park, H. S. ve Ahn, J. Y. (2007). Cultural differences in judgment of truthful and deceptive messages. Western Journal of Communication, 71(4), 294-315.

Park, H. S., Choi, H. J., Oh, J. Y. ve Levine, T. R. (2018). Differences and similarities between Koreans and Americans in lying and truth-telling. Journal of Language and Social Psychology, 37(5), 562-577.

Schermelleh-Engel, K., Moosbrugger, H. ve Müller, H. (2003). Evaluating the fit of structural equation models: Tests of significance and descriptive goodness-of-fit measures. Methods of Psychological Research Online, 8(2), 23-74.

Schwartz, S. H. ve Bilsky, W. (1990). Toward a theory of the universal content and structure of values: Extensions and cross-cultural replications. Journal of Personality and Social Psychology, 53, 550-562.

Serota, K. B., Levine, T. R. ve Boster, F. J. (2010). The prevalence of lying in America: Three studies of reported deception. Human Communication Research, 36, 1-24.

Sims, R. L. (2002). Support for the use of deception within the work environment: A comparison of Israeli and United States employee attitudes. Journal of Business Ethics, 35(1), 27-34.

Triandis, H. C., Carnevale, P., Gelfand, M., Robert, C., Wasti, A., Probst, T., . . Schmitz, P. (2001). Culture and deception in business negotiations: A multilevel analysis. International Journal of Cross-Cultural Management, 1, 73-90. 


\section{Ek-1 Yalanın Uygunluğu Ölçeği}

Aşağıdaki maddelerde, farklı durumlarda ortaya çıkan yalanlara ilişkin kısa hikâyeler bulunmaktadır. Lütfen, her bir hikâyede ana karakterin söylediği yalanların sizin için ne kadar uygun olup olmadığını 5'li ölçek ( $1=$ hiç uygun değil; 5= çok uygun) üzerinden değerlendiriniz.

\begin{tabular}{|c|c|c|c|c|c|}
\hline & $\begin{array}{c}\text { Hiç Uygun } \\
\text { Değil }\end{array}$ & $\begin{array}{l}\text { Uygun } \\
\text { Değil }\end{array}$ & Kararsızım & Uygun & $\begin{array}{l}\text { Çok } \\
\text { Uygun }\end{array}$ \\
\hline $\begin{array}{l}\text { 1.Uyuyakaldığ } 1 \text { için sınava yetişemeyen } \\
\text { Derya'yı hocası sorduğunda Müge, Derya'nın } \\
\text { trafik nedeniyle geç kaldığııı söyledi. }\end{array}$ & & & & & \\
\hline $\begin{array}{l}\text { 2.Gamze, aldığ } 1 \text { hediye hoşuna gitmese de } \\
\text { Mine'ye hediyeyi beğendiğini söyledi. }\end{array}$ & & & & & \\
\hline $\begin{array}{l}\text { 3. Metin evde olmasına rağmen rahatsı edilmek } \\
\text { istemediği için kendisini defalarca arayan } \\
\text { Kenan'a uygun bir ortamda olmadı̆̆ını söyledi. }\end{array}$ & & & & & \\
\hline $\begin{array}{l}\text { 4.Arda iş mülakatında işe kabul edilmek için } \\
\text { kullanmayı bilmediği programları bildiğini } \\
\text { söyledi. }\end{array}$ & & & & & \\
\hline $\begin{array}{l}\text { 5.Osman yöneticisinin verdiği işi yapmak } \\
\text { istemediği için öyle olmadığı halde ona hastane } \\
\text { randevusu olduğunu söyledi. }\end{array}$ & & & & & \\
\hline $\begin{array}{l}\text { 6. Selda, evliliği hakkında soru soran arkadaşı } \\
\text { Gizem'e yaşadığı problemlerin aile içinde } \\
\text { kalmasını istediği için her şeyin yolunda } \\
\text { olduğunu söyledi. }\end{array}$ & & & & & \\
\hline $\begin{array}{l}\text { 7. Salih, işe geciken Murat'ı sorduklarında onu } \\
\text { sabah ofiste gördüğünü söyledi. }\end{array}$ & & & & & \\
\hline $\begin{array}{l}\text { 8. Sema, Esra'y1 mutlu etmek için, izlemek } \\
\text { istemediği halde filmi çok merak ettiğini } \\
\text { söyledi. }\end{array}$ & & & & & \\
\hline $\begin{array}{l}\text { 9. Banu, evlerini ayıran Çağla ve Deniz'e öyle } \\
\text { olmadığ } 1 \text { halde ikisinin de birbirlerini } \\
\text { özlediklerini söyledi. }\end{array}$ & & & & & \\
\hline $\begin{array}{l}\text { 10. İsmail, patronuyla sorun yaşıyor olmasına } \\
\text { rağmen, Sedat işini sorunca konuyu geçiştirmek } \\
\text { için işinde mutlu olduğunu söyledi. }\end{array}$ & & & & & \\
\hline $\begin{array}{l}\text { 11. İşe geç kalmaktan korkan Seren, yol tarifi } \\
\text { soran birine adresi bildiği halde işine } \\
\text { gecikmemek için bilmediğini söyledi. }\end{array}$ & & & & & \\
\hline $\begin{array}{l}\text { 12. Eren hastalığ nedeniyle kötü görünüyor } \\
\text { olmasına rağmen, daha fazla üzülmesin diye } \\
\text { Can ona toparlamış olduğunu söyledi. }\end{array}$ & & & & & \\
\hline $\begin{array}{l}\text { 13. Canan, ödevine yardım etmesi için Başak'1 } \\
\text { 1srarlı bir şekilde arayınca Başak, rahatsız } \\
\text { edilmek istemediği için işi olmadığ halde bir } \\
\text { işi olduğunu söyledi. }\end{array}$ & & & & & \\
\hline $\begin{array}{l}\text { 14. Hatasından dolayı Fatih'in işini } \\
\text { kaybetmemesi için, Tolga yöneticiye Fatih'in } \\
\text { hatalı olmadığın söyledi. }\end{array}$ & & & & & \\
\hline $\begin{array}{l}\text { 15.Gül, kendisinin nasıl olduğunu soran } \\
\text { Dilara'ya o dönem boğuştuğu sorunları } \\
\text { anlatmayıp konuyu geçiştirmek istediği için iyi } \\
\text { olduğunu söyledi. }\end{array}$ & & & & & \\
\hline $\begin{array}{l}\text { 16.Faruk, kendisini iyi göstermek için öyle } \\
\text { olmadığ } 1 \text { halde Tufan'a uluslararası turnuvada } \\
\text { madalya aldığını söyledi. }\end{array}$ & & & & & \\
\hline
\end{tabular}




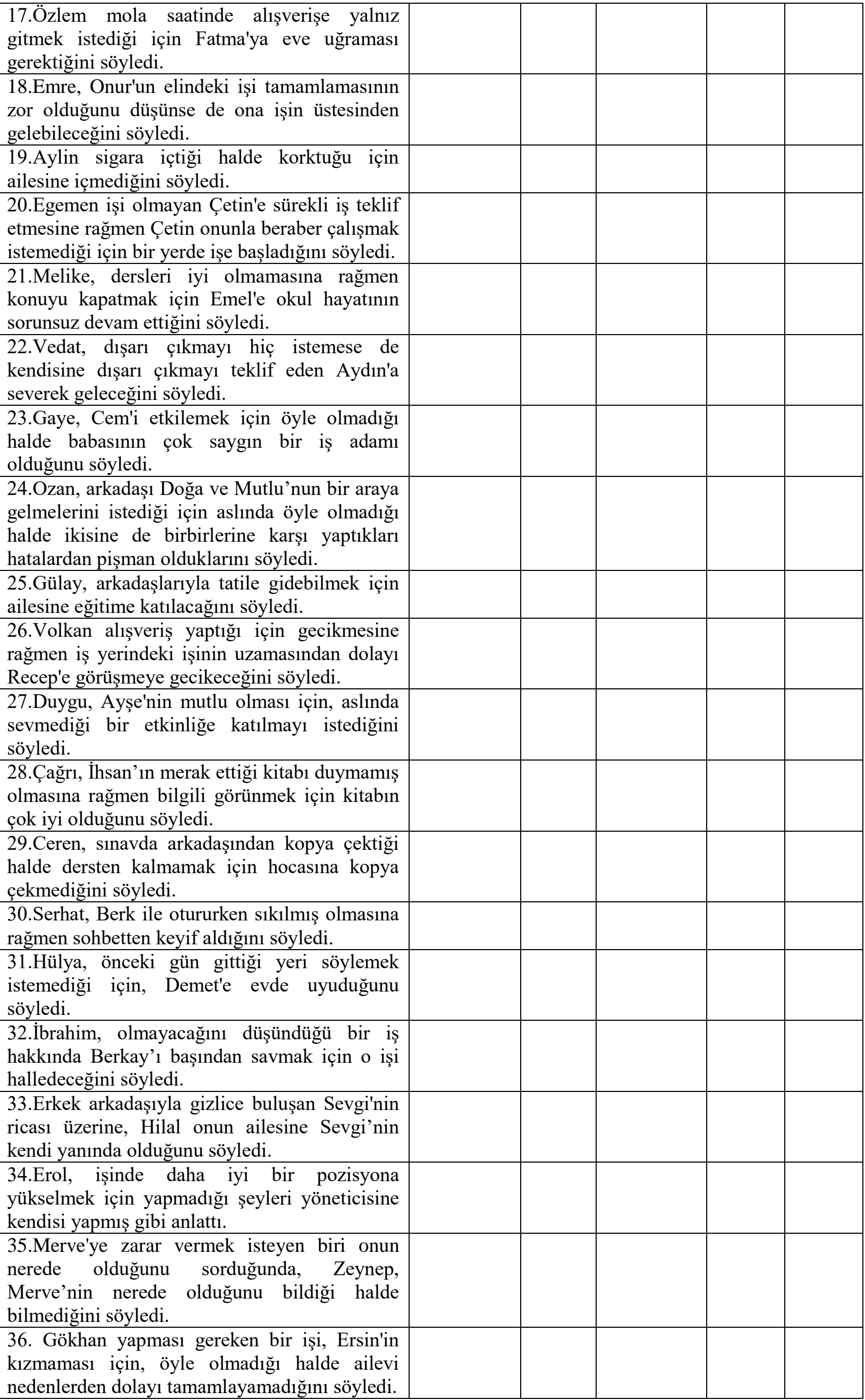




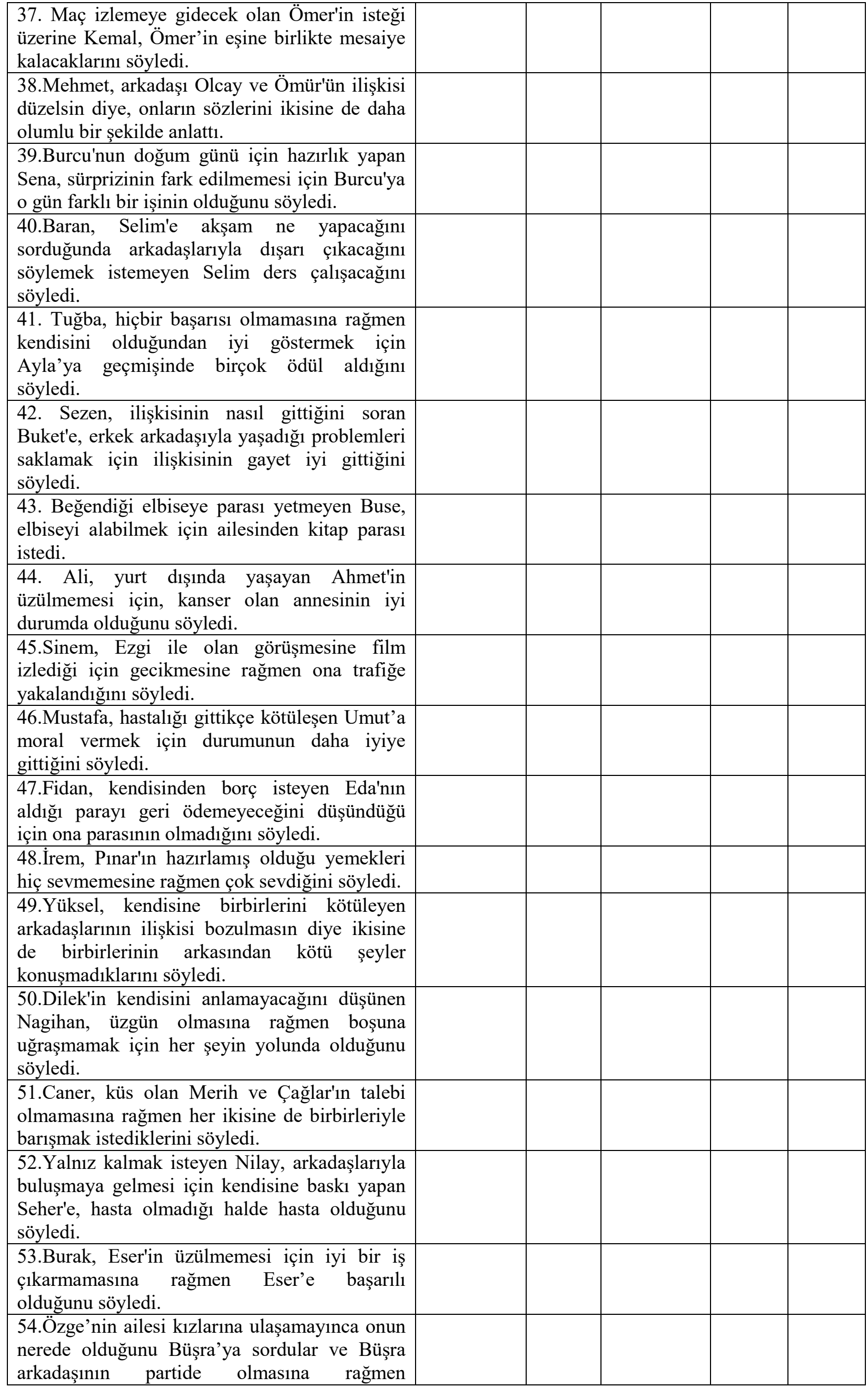




\begin{tabular}{|l|l|l|l|l|l|}
\hline kütüphanede olduğunu söyledi. & & & & & \\
\hline $\begin{array}{l}\text { 55.Tayfun, geçimini zor sağlamasına rağmen } \\
\text { Ferhat'a mahcup olmamak için lüks bir hayatı } \\
\text { olduğunu söyledi. }\end{array}$ & & & & & \\
\hline $\begin{array}{l}\text { 56.Naz, ödevine ek süre alabilmek için } \\
\text { hocasına ailesinden birinin rahatsızlandığını } \\
\text { söyledi. }\end{array}$ & & & & & \\
\hline $\begin{array}{l}\text { 57.Sezer uyuyakaldığı için işe geç kalmış } \\
\text { olmasına rağmen iş yerine vardığında } \\
\text { Armağan'a hastalandığından dolayı geciktiğini } \\
\text { söyledi. }\end{array}$ & & & & & \\
\hline $\begin{array}{l}\text { 58.Hande, aslında hiç beğenmese de Aslı'ya } \\
\text { yeni saç modelinin çok yakıştığını söyledi. }\end{array}$ & & & & & \\
\hline $\begin{array}{l}59 . \text { Serdar, istemediği bir yere kendisini israrla } \\
\text { çağıran Erhan'a herhangi bir işi olmadığı halde }\end{array}$ & & & & & \\
işi olduğu için gelemeyeceğini söyledi. & & & & & \\
\hline
\end{tabular}

